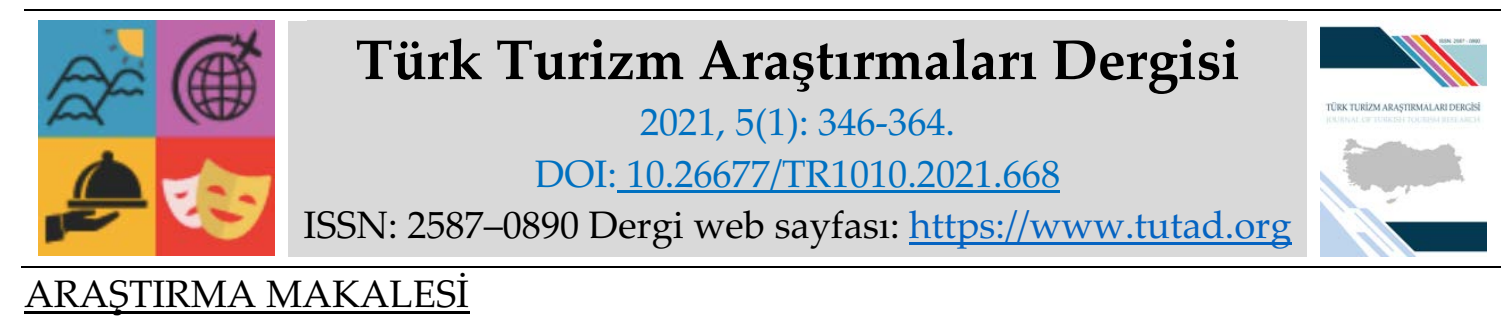

\title{
Otel İşletmelerinde Rekabet Üstünlüğ̈̈ Sağlayan Kritik Başarı Faktörleri: Trabzon İlindeki 4 ve 5 Yıldızlı Oteller Üzerine Bir Araştırma
}

Muhammet Caner KAYA, Doktora Öğrencisi, Sakarya Uygulamalı Bilimler Üniversitesi, Lisansüstü Eğitim Enstitüsü, Sakarya, e-posta: muhammetcanerkaya@trabzon.edu.tr

ORCID: https://orcid.org/0000-0001-9975-8011

Prof. Dr. Orhan BATMAN, Sakarya Uygulamalı Bilimler Üniversitesi, Turizm Fakültesi, Sakarya, e-posta: obatman@subu.edu.tr

ORCID: https://orcid.org/0000-0001-7186-7064

Prof. Dr. Oğuz TÜRKAY, Sakarya Uygulamalı Bilimler Üniversitesi, Turizm Fakültesi, Sakarya, e-posta: turkay@subu.edu.tr

ORCID: https://orcid.org/0000-0002-0752-6799

Öz

Rekabetin son derece arttığı günümüz dünyasında, işletmelerin yaşamlarını idame ettirebilmesi için sürdürülebilir rekabet üstünlügü elde etmesi gerekmektedir. İşletmeler, sadece kendi süreçlerine bakarak değil, dış çevreyi ve bilhassa rakiplerinin hareketlerini de göz önüne alarak gerekli adımlar atmaya ihtiyaç duymaktadırlar. Özellikle turizm endüstrisinin çok sayıdaki özelliğinden dolayı talebin aşırı esnek olması, turizm işletmelerinin gelecek ile alakalı bir adım atacağı zaman göz önünde bulundurması gereken faktörleri daha da artırmakta ve bu faktörler kritik öneme sahip olmaktadır. Çalışmanın amacı Trabzon ilindeki otel işletmelerinin başarı ve rekabet avantajı sağlaması için odaklanması gereken faktörleri tespit etmektir. Araştırma verilerinin bir kısmı nicel, bir kısmı nitel yöntemlerle toplanmıştır. 19 otel yöneticisine yapılan anket ile nicel veriler, 10 otel yöneticisi ile yapılan yapılandırılmamış mülakat ile nitel veriler toplanmıştır. Nicel verilerin analizinde ortalama ve standart sapma analizi, nitel verilerin analizinde ise tek vaka modeli, iki vaka modeli ve kelime bulutu kullanılmıştır. Araştırma sonuçlarına göre otel yöneticilerinin en önemli gördükleri Kritik Başarı Faktörlerinden (KBF) bazıları şöyle sıralanabilir: ek hizmetler (konaklama gelirleri haricinde gelir getirici, işletmenin çekiciliğini de artırabilecek aynı zamanda tesislerde konaklayan misafirler haricinde de kullanımı sağlanabilecek hizmetler), gelen misafirler arasında tekrar gelen misafir oranının fazlalı̆̆ı, misafir ile iletişim, otel odalarının dizaynı ve kalitesi, misafir tavsiyeleri, uluslararası marka oluşturma ve işletmenin sosyal medyadaki etkinliği.

Anahtar Kelimeler: Stratejik Yönetim, Kritik Başarı Faktörleri, Otel İşletmesi, Trabzon.

Makale Gönderme Tarihi: 08.10.2020

Makale Kabul Tarihi: 04.03.2021

Önerilen Atıf:

Kaya, M. C., Batman, O. ve Türkay, O. (2021). Otel İşletmelerinde Rekabet Üstünlüğü Sağlayan Kritik Başarı Faktörleri: Trabzon İlindeki 4 ve 5 Yıldızlı Oteller Üzerine Bir Araştırma, Türk Turizm Araştırmaları Dergisi, 5(1): 346-364.

(C) 2021 Türk Turizm Araştırmaları Dergisi. 


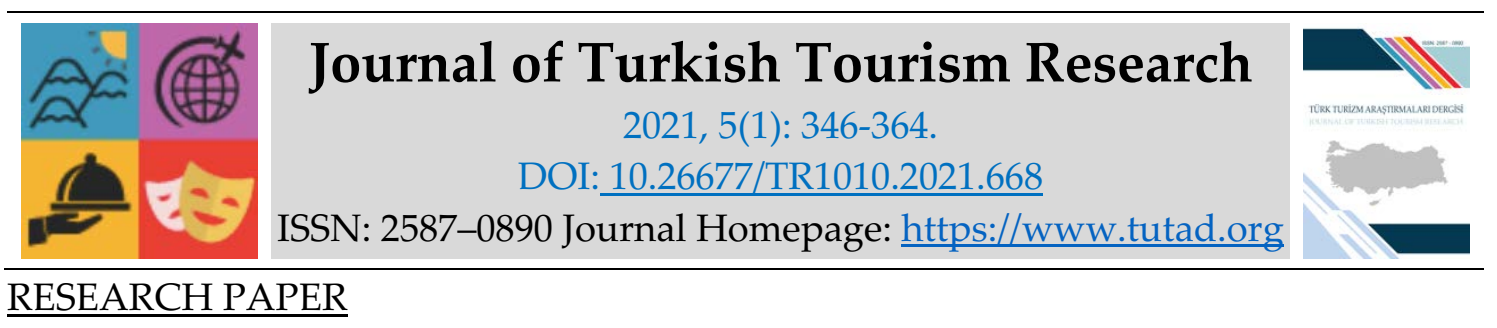

\title{
Critical Success Factors Providing Competitive Advantage in Hotel Businesses: A Research on 4- and 5-Star Hotels in Trabzon Province
}

\author{
Muhammet Caner KAYA, Ph.D. Student, Sakarya University of Applied Sciences, Graduate Education \\ Institute, Sakarya, e-mail: muhammetcanerkaya@trabzon.edu.tr \\ ORCID: https://orcid.org/0000-0001-9975-8011
}

Prof. Dr. Orhan BATMAN, Sakarya University of Applied Sciences, Faculty of Tourism, Sakarya, e-mail: obatman@subu.edu.tr ORCID: https://orcid.org/0000-0001-7186-7064

Prof. Dr. Oğuz TÜRKAY, Sakarya University of Applied Sciences, Faculty of Tourism, Sakarya, e-mail: turkay@subu.edu.tr

ORCID: https://orcid.org/0000-0002-0752-6799

\begin{abstract}
In today's world where competition is extremely increasing, businesses need to achieve a sustainable competitive advantage in order to survive. Businesses need to take the necessary steps not only by looking at their own processes, but also by considering the external environment and especially the actions of their competitors. The excessive flexibility of demand, especially due to many features of the tourism industry, increases the factors that tourism businesses should take into account when they take a future-related step, and these factors have critical importance. The aim of the study is to determine the factors that should focus on hotel businesses in Trabzon province in order to achieve success and competitive advantage. Some of the research data were collected by quantitative and some qualitative methods. Quantitative data were collected with a questionnaire for 19 hotel managers, and qualitative data were collected through unstructured interviews with 10 hotel managers. Mean and standard deviation analysis were used in the analysis of quantitative data, while a single case model, two case models and word cloud were used in the analysis of qualitative data. According to the results of the research, some of the Critical Success Factors (KBF) that hotel managers consider to be the most important can be listed as follows: additional services (incomegenerating excluding accommodation income, services that can increase the attractiveness of the business and can be used other than the guests staying in the facilities), excess, communication with guests, design and quality of hotel rooms, guest recommendations, building an international brand and the effectiveness of the business in social media.
\end{abstract}

Keywords: Strategic Management, Critical Success Factors, Hotel Management, Trabzon.

Received: 08.10.2020

Accepted: 04.03.2021

Suggested Citation:

Kaya, M. C., Batman, O. and Türkay, O. (2021). Critical Success Factors Providing Competitive Advantage in Hotel Businesses: A Research on 4- and 5-Star Hotels in Trabzon Province, Journal of Turkish Tourism Research, 5(1): 346-364.

(C) 2021 Türk Turizm Araştırmaları Dergisi. 


\section{Gíriş}

Stratejik yönetim, bir organizasyonun gelecekte varmak istediği hedefleri ve bu hedefe nasıl ulaşacağını gösteren süreci analiz eden bir teknik (Barry, 1986: 10) olan, kısaca; uzun dönemde işletmenin yaşamını sürdürmesi ve rekabet üstünlügüünü sağlamasını amaçlayan bir yönetim biçimi (Ülgen ve Mirze, 2013: 56) olarak açıklanmaktadır. Bryson (1995: 5) stratejik yönetimi “bir organizasyonun ne yaptığını, varlık sebebini ve gelecekte ulaşmak istediği hedefleri ortaya koyan bir yönetim tekniği" olarak açıklamaktadır. Yapılan tanımlardan yola çıkarak, stratejik yönetimin odaklandığg konular; "işletmenin sürdürebilirliği, rekabet üstünlügü, geleceğe yönelik kararlar, iç ve dış çevrenin tanınması, ulaşılmak istenen hedefler ve bu hedeflere nasıl ulaşılacağı" olduğu söylenebilir.

Literatürde "critical success factors (CSFs)" kavramı karşılığında "kritik beceriler-critical skills", "anahtar başarı faktörleri" ve "kritik başarı faktörleri" olarak kullanımı olan "KBF" (Filizözü, 2010:3), Massachusetss teknoloji enstitüsünden Rockart tarafından 1970'lerde, başarılı stratejik yönetim için gerekli olan anahtar bilgi ihtiyaçlarını belirlemek maksadıyla geliştirilmiştir (Hussey, 1998:162; Acar ve Özçelik, 2011:11; Wohlfeil ve Terzidis, 2014:1). KBF, ilk olarak 1961 yılında Daniel tarafından ortaya konmuş, üst düzey yönetim aktivitelerinin desteklenmesi için ihtiyaç duyulan bilgi türlerine vurgu yapılmıştır (Butler ve Fitzgerald, 1999:352; Cooper, 2010).

Kritik başarı faktörleri, yöneticilerin hedeflerine ulaşabilmeleri ve işletmenin büyüyebilmesi için “doğru olması gereken” birkaç anahtar alandır. (Rockart, 1979; Bullen ve Rockart, 1981: 7). Başka bir deyişle; kritik başarı faktörleri, başarıya ulaşmak için dikkat edilmesi gereken "işin püf noktaları" dır (Ülgen ve Mirze, 2013: 134). KBF, stratejik düşünmenin ilk döneminde işletmenin zayıflık ve üstünlüklerinin belirlenmesinde yani; işletmenin içsel durumunun değerlendirilmesinde kullanılan bir yaklaşımdır. Hussey'e göre (1998), faaliyet gösterilen pazarda başarılı olmak isteyen işletme, sektörün gerektirdiği kritik başarı faktörlerinde üstün olmak durumundadır. İşletme, KBF'nden birinde zayıf ise stratejik zayıflık içerisindedir (Yüksel ve Dağdeviren, 2009: 576).

Bir işletmenin başarıya ulaşabilmesi için gerekli birçok faktör bulunmaktadır. Bu faktörlerin her biri aynı önem derecesinde olmayabilir ve ayrıca bunların tümüne odaklanmak zaman ve maddiyat gibi maliyet kısıtları yüzünden zor olabilir. Bu durumda, başarı için belirlenen faktörler arasından seçim yapmak ve işletme için kritik görülenler üzerinde odaklanmak gerekebilir. KBF bu faktörler arasında kritik-anahtar öneme sahip faktörlerin belirlenip bunlar üzerinde odaklanmayı mümkün kılan bir yaklaşımdır.

İşletmelerde kritik başarı faktörleri iki grupta toplanabilir. Bunlar (Ülgen ve Mirze, 2013: 152); (1) çıktı miktarı, çıkı kalitesi, karlılık unsurları gibi işletmenin büyümesi ile ilgili faktörler ve (2) pazarda bulunan işletmelerin sayısı, rekabetin şiddet derecesi, kapasite durumları gibi unsurlardan oluşan sektördeki rekabet durumu ile ilgili faktörlerdir.

Filizözü'ne göre (2010: 53), kritik başarı faktörlerinin yararları şunlardır: (1) Yöneticilerin bu faktörleri devamlı gözleyerek önemli konulara dikkatini toplamasına yardımcı olur. (2) Bu faktörlerin ölçülebilmesi için performans ölçütlerini bulmaya zorlayarak organizasyonun fonksiyonel tabanda ve genel olarak başarısının ölçülmesini sağlar. (3) Organizasyonun daha iyi planlama yapmasına yardımcı olur. (4) KBF hiyerarşisi (endüstri, işletme, yönetici $\mathrm{KBF}^{\prime}$ leri) yönetim içindeki iletişimin artmasını sağlar. (5) Organizasyonun dış etkileri daha sağlıklı dikkate almasını ve sistemin günün koşullarına uyum göstermesini sağlar. (6) Organizasyonun rekabetçi konumunu etkileyebilecek olan bilgi sağlamada ve sezgilerin geliştirilmesinde etkilidir. (7) 
Direktif olmayan (non-directive) danışmanlık teknikleri şeklinde yürütülüyor olması, yaratıcılığ1 ve özgür düşünceleri destekler ve geliştirir.

Esasen, kritik başarı faktörleri hem işletme içinde hem de dış işletim ortamında "ulaşılması gereken" faktörlerdir. "Başarı"ya yapılan bu vurgu KBF'nin bir başka önemli özelliğini, yani eyleme yönelik olduklarını vurgular. KBF bir amaç için araçtır, kendi başlarına bir amaç değildir (Brotherton ve Shaw, 1996: 114).

Yapılan araştırma, stratejik yönetim anlayışı kapsamında, otel işletmelerinin rekabet üstünlügü oluşturması ve bunu sürdürülebilir hale getirmesini sağlayan kritik başarı faktörlerini tespit etmeye yöneliktir. Bu amaçla Trabzon ilindeki 4 ve 5 yıldızlı otel işletmelerini yöneticileri ile görüşülerek kritik başarı faktörleri belirlenmeye çalışılmıştır.

\section{TURIZM ENDÜSTRİIINDE KBF}

Çiçek Gökalp (2003), küçük ölçekli konaklama işletmelerinin yönetiminde KBF'ni “kurum içi” ve "kurum dışı" olarak ayırıp tespitlerde bulunmuştur. Kurum içi KBF; (1) Fiyatları çekici hale getirme, (2) Etkin tanıtım, (3) Maliyetleri en düşük seviyeye çekme, (4) Müşteri memnuniyetine dikkat etme, (5) İyi planlanmış ve inşa edilmiş bina. Kurum dışı KBF ise; (1) Ülkedeki ekonomik istikrar, (2) Hükümetin turizme bakışı ve yaklaşımı, (3) Hükümetin döviz politikası, (4) Hükümet ve yerel yönetimlerin küçük işletmelere yönelik teşvikleri, (5) Küçük işletmelere yönelik yasal olanaklar olarak sıralanmıştır.

Abdullah ve Hamdan (2012), otel doluluk oranının iç başarı faktörlerini inceledikleri araştırmalarını 135 katılımcıyla Malezya'da gerçekleştirmiştir. Araştırmada genel olarak şu sonuçlara ulaşılmıştır; otel operasyonunun başarısının, otelin müşterilerin beklentilerini ne kadar iyi karşılayıp karşılamadığına bağlı olduğunu göstermektedir. Bu beklentilerin aşılması müşteri memnuniyetini beraberinde getirecektir. Özellikle, otel endüstrisinin başarısı büyük ölçüde yönetimin müşterilerin ihtiyaç ve isteklerini belirleme ve anlama becerisine bağlıdır. Demografik geçmişe bağlı olarak, müşterilerin seçimleri ve ihtiyaçları birbirinden farklıdır, ancak aynı ortak ihtiyaçlara sahiptirler ki bu kaliteli hizmettir. Kaliteli hizmet vermek sadece otel çalışanının sağladığı niteliklerle değil, aynı zamanda otel tesisleri ve ortamıyla da sinırlıdır. Bir otel müşterilerin beklentilerini karşılayabildiğinde veya aşabildiğinde, memnuniyet seviyesi artar. Memnuniyet daha sonra aynı otele geri dönme isteğine ve başkalarına aynı otelde kalmalarını tavsiye etme eğilimine yol açacaktır.

Yiyecek-içecek sektörü, emek-yoğun olması, marka bağımlılığının az olması, ikame ürünlerin çokluğu, sektöre giriş ve çıkış kolaylığı gibi birtakım özellikleri bakımından ele alındığında (Türkay, Kaya ve Birer, 2013: 1000), işletmelerin pazarda rekabet üstünlüğü elde etmesi ve bu üstünlügünü sürdürülebilir hale getirebilmesi diğer sektörlere göre çok daha zorlu ve süreklilik gereken bir süreç olabilmektedir. Bu sebeple, sektörde yer alan işletmelerin başarılı olabilmesi için sektörü tanıması, başarı faktörlerini iyi irdelemesi ve bunların arasından kritik olanları belirleyip onlara odaklanması elzem bir gereklilik olabilir. KBF yaklaşımı ile yiyecek-içecek işletmeleri yukarıda belirtilen durumları daha sistematik yapabilirler.

Yiyecek-içecek alanında kritik başarı faktörleri her işletmeye göre değişebilir. Bu alanda yapılmış daha önceki çalışma sayısı sınırlıdır. Davis ve Stone (1988); yiyecek ve içecek kalitesi, menü çeşitliliği, servis düzeyi, fiyat ve ödeme gücü, tasarım, atmosfer, müşteri beklentileri, konum ve ulaşılabilirlik, servis elemanları gibi faktörlerin bir yiyecek-içecek işletmesinde stratejilerin 
belirlenmesinde etkili olduğunu belirtmişlerdir (Güler, 2007: 103). Dipietro vd., (2007) çok şubeli yiyecek-içecek işletmeleri üzerinde yaptıkları araştırmada tespit ettikleri kritik başarı faktörlerini sekiz ana başlıkta toplayarak ortaya koymuşlardır. Bunlar; (1) Münferit Birimli Operasyonlar (Maliyetlerin kontrolü, personelin eğitimi, tesislerin bakımı), (2) Standart iş görme prosedürleri (Raporların doldurulması, verilerin toplanması, ürün temini ve yönlendirme), (3) Çok birimli stratejik Planlama (Hedeflerin ayarlanması, Bütçeleme ve Kriz Yönetimi), (4) Kişiler arası sosyal görevler (toplum ilişkileri, yöneticilerin gelişimi ve yiyecek güvenliği), (5) Takip birimi (Seyahat ve şubeleri ziyaret-teftiş), (6) İnsan Kaynakları (Değerlerin modellenmesi, takımın kurulması, kalitenin gelişimi), (7) Etkili Liderlik (Bölge kaynağı, Satışların yükselmesine odaklanmak), (8) Finans Birimi (Finansal kararlar, rakiplerin takibi ve şube bazında kiralama).

Müşterilerin yiyecek-içecek işletmesi seçimini etkileyen faktörler işletmenin başarıya ulaşmak için odaklanacağ faktörler olarak da görülebilir. Albayrak (2014: 191-192), önceki çalışmalar 1şığında müşterilerin bir yiyecek-içecek işletmesini seçimlerinde etkili olan faktörleri; "Atmosfer, menü/yemek çeşitliliği, yemeklerin kalitesi/sağlıklı olması, fiyat, bölge, temizlik, mal/hizmet kalitesi, kalabalık, çalışanların davranışları, servis hızı, besin içeriği, rahatlık, çocuk opsiyonu, işletmenin çalışma saatleri, işletme imajı ve ödenen paranın karşıllğı" olarak belirlemiştir. DiPietro, Parsa ve Gregory (2011: 984) önceki çalışmaları tarayarak, müşterilerin hızlı servis yapan yiyecek-içecek işletmelerini (quick-service restaurants) tercih etme motivasyonlarını en çok etkileyen faktörlerin "kalite, hizmet ve temizlik" (quality, service, cleanliness) olduğunu tespit etmişlerdir. Arsezen-Otamış'ın (2015) araştırmasında yiyecek-içecek işletmelerini “yemek, hizmet, değer (fiyat, fayda/maliyet) ve atmosfer" kritik başarı faktörlerine göre değerlendirilip performans analizi yapılmıştır.

Baker ve Cameron (2007); destinasyon pazarlamasında kritik başarı faktörleri isimli araştırmalarında, literatür taraması sonucu 4 kategori halinde kümelenmiş 33 adet kritik başarı faktörü tespit etmişlerdir. Araştırmacılar tarafından bu kategoriler; (1) Stratejik Yönelim (Strategic Orientation), (2) Destinasyon Kimliği ve İmajı, (3) Paydaş Katılımı (Stakeholder involment) ve (4) Uygulama, İzleme ve İnceleme (Implementation, Monitoring and Review) olarak belirlenmiştir.

McLaren (2011); Sürdürülebilir Kırsal Turizm Destinasyonlarının pazarlanmasında KBF'ni belirlemek maksadıyla yaptığı araştırma sonucunda 5 kategori halinde toplam 16 kritik başarı faktörü bulmuştur. Bu kategoriler; (1) Güçlü bir destinasyon kimliği ve marka oluşturmak (2) Eşsiz bir deneyim sağlamak (3) Destinasyondaki ürün çeşitliliğini dengelemek, (4) Tüm paydaşların destinasyonu tanıtması ve (5) Elektronik ortamları etkin kullanmak olarak belirlenmiştir.

Hughes ve Carlsen (2010), kültürel miras turizmi operasyonu için gerekli kritik başarı faktörlerini ve bunların ticari odaklanma ile nasıl ilişkili olduğunu araştırdıkları çalışmalarında 9 faktör belirlemişlerdir. Bunlar; (1) Kararlaştırılan hedefler ve net kavramlar, (2) Finansal Planlama, (3) Pazarlama Stratejileri, (4) Pazarları ve akışları izleme, (5) Etkili İnsan Kaynakları Yönetimi (ücretli çalışanlar ve gönüllüler dahil), (6) Ürün farklılaştırmasının planlanması, yaşam evresi ve değer artırımı, (7) Ürün ve deneyimlerin kalitesi ve özgünlüğü, (8) Kültürel miras ve turizm uzmanlığının himaye edilmesi ve teşvik edilmesi ve (9) Yorumlamanın (Interpretation) Kültürel Miras turizmi deneyiminin ayrılmaz bir parçası olarak görülmesi olarak sıralanmıştır.

Seyahat acentelerinin kritik başarı faktörlerini belirleyen çok fazla çalışma yapılmamıştır. Bu alandaki çalışmaların çoğu tüketicilerin seyahat acentelerini tercih etmelerine neden olan 
faktörleri belirleyen araştırmalar olmuştur. Touche Ross ve Company (1978) tarafından yapılan bir çalışma sonucunda, seyahat uzmanlığının acente kullanımının en önemli nedeni olarak sıralandığı ortaya çıkmıştır. Hruschka ve Mazanec (1990), seyahat acenteleri tarafından sağlanan danışmanlık kalitesinin rakip acenteler arasında önemli bir farklılaşma faktörü olduğu yorumunu yapmıştır. LeBlanc (1992), turistlerin, seyahat acentelerinin hizmet kalitesine ilişkin algılarını kategorize eden dokuz faktör belirlemiştir. Bulguları, bir seyahat acentesinin kurumsal imajının, seyahat edenlerin acentenin hizmet kalitesiyle ilgili değerlendirmesini etkileyen en belirleyici faktör olarak görüldüğünü ortaya çıarmıştır. Persia ve Gitelson (1993), tüketicilerin seyahat acentesi performansını beş genel hizmet yönüne göre değerlendirmelerini önermiştir. Bunlar; bilgi arama, teknik rezervasyon becerisi, fiziksel kalite, kurumsal kalite ve interaktif kalitedir. Meidan (1979) iki grup katılımcının (45 yaş altı ve 45 ve üstü yaş grupları) yurt dişı paket tur için bir seyahat acentesi seçimini etkileyen faktörleri belirlemiş ve karşılaştırmıştır. 45 yaşın altındaki katılımcılar, kendileri için en önemli olanların; (1) kurumun iletişim yeteneği, (2) uçuş sırasında ve oteldeki hizmet kalitesi, (3) acenteye erişim kolaylığı, (4) fiyat ve (5) sunulan çeşitli paket tur içeriği olduğu ortaya çıkmıştır. 45 yaş ve/ya üstü katılımcılar için en önemlileri ise; (1) uçuş sırasında ve oteldeki hizmet kalitesi, (2) acenteye erişim kolaylığı, (3) reklam, (4) fiyat ve (5) rezervasyon hizmetidir (Heung ve Chu, 2000:53).

Heung ve Chu (2000), her şey dahil paket turlar için bir seyahat acentesi seçmeye ilişkin önemli seçim faktörlerini belirlemeyi amaçladıkları çalışmalarında, "Acentenin itibarı", "sözlü iletişim", "personelin tutumu", "ödenen miktarın karşılığının alınması" ve "geçmiş deneyim" seyahat acentesi seçiminde en önemli beş özellik olarak ortaya konmuştur. 29 seçenekten, insanların her şey dahil bir tur paketi tercihlerini etkileyen altı seyahat acentesi seçim unsuru faktör analizinden türetilmiştir. Bunlar; Etkileşimli Acente Kalitesi, Resmi İletişim, Genel Kolaylık, Fiyatlandırma, Ürün Özellikleri ve İmaj faktörleridir. Yapılandırılmış sorulara ek olarak, katılımcılardan her şey dahil bir tur paketi için seyahat acentesini düşünürken önemli faktörleri belirleyecekleri açık uçlu bir soru geliştirilmiştir. Bu açık uçlu sorunun sonuçları, katılımcıların her şey dahil paket tur için bir seyahat acentesi seçerken dikkate aldıkları faktörler olarak belirlenmiştir. Bunlar; "Acentenin Güvenilirliğì", "Acentenin Dürüstlüğü", "Acentenin büyüklüğü" ve "Acentenin Turistlerin İhtiyaçlarını Karşılama Yeteneği" dir.

Konu üzerine daha çok yapılan araştırmalar turizm endüstrisinde arz üreten çeşitli işletmelerin rekabet ortamında avantaj sağlamak için kritik olarak gördükleri faktörleri ortaya koymuştur. Genel olarak bakıldığında işletmeler, kendilerini tercih eden misafirlerin beklentilerini karşılamak, onları memnun edip tekrardan kendilerini tercih etmelerini sağlamak için çaba sarf etmektedirler. Her sektör için hatta her işletme açısından KBF'nin farklılaştı̆̆ gözlemlenmekle birlikte ortak KBF'nin varlığı görülmektedir. Bunlar; Fiyat (ödenen ücretin karşıllı̆ı), reklam ve etkin tanıtım, hizmet kalitesi, müşteri beklentilerinin karşılanması, müşteri ile etkin iletişim faktörleridir. Araştırmada bu faktörlerin Trabzon ilindeki otel yöneticileri için önemi de irdelenmekle birlikte varsa önem verdikleri farklı faktörlerin varlı̆̆ı araştırılmaktadır.

\section{YÖNTEM}

Bir şehrin konaklama imkanlarının bölgenin turizm destinasyonu olarak lanse edilmesinde önemli bir rol oynadığı gerçeği göz önünde bulundurulduğunda otel işletmelerinin rekabet ortamında başarılı olabilmesi için izleyecekleri yolların tespiti de elzem olabilmektedir. Çalışmada tam olarak bu amaçlanmaktadır. Bir başka deyişle; çalışmanın amacı Trabzon ilindeki otel işletmelerinin başarı ve rekabet avantajı sağlaması için odaklanması gereken faktörleri tespit etmektir. 
Çalışmanın evreni Trabzon ilindeki 4 ve 5 yıldızlı otellerdir. Tablo 1'de Trabzon ilindeki 4 ve 5 yıldızlı otellerin listesi verilmiştir. Çalışmanın örneklemi çalışma evreninin bütününü kapsamaktadır.

Tablo 1. Trabzon İlindeki 4 ve 5 Yıldizlı Oteller (2020)

\begin{tabular}{|l|l|l|l|l|}
\hline \multicolumn{1}{|c|}{ Otel Adı } & Yıldızı & $\begin{array}{l}\text { Bulunduğu } \\
\text { İlçe }\end{array}$ & $\begin{array}{l}\text { Oda } \\
\text { Sayısı }\end{array}$ & $\begin{array}{l}\text { Yatak } \\
\text { Sayısı }\end{array}$ \\
\hline Royal Comfort Otel & 4 Yıldızlı & Araklı & 55 & 110 \\
\hline Sera Lake Hotel & 4 Yıldızlı & Akçaabat & 20 & 40 \\
\hline Tilya Resort Hotel & 4 Yıldızlı & Akçaabat & 100 & 200 \\
\hline Uzungöl Önder Hotel\&Spa (Flora) & 4 Yıldızlı & Çaykara & 69 & 148 \\
\hline Kilpa Otel & 4 Yıldızlı & Çaykara & 48 & 96 \\
\hline Royal Uzungöl Otel & 4 Yıldızlı & Çaykara & 57 & 114 \\
\hline Maçka Büyük Sümela Otel & 4 Yıldızlı & Maçka & 115 & 230 \\
\hline Funda Otel & 4 Yıldızlı & Ortahisar & 51 & 114 \\
\hline Saylamlar Hotel & 4 Yıldızlı & Ortahisar & 66 & 132 \\
\hline Usta Park Otel & 4 Yıldızlı & Ortahisar & 120 & 245 \\
\hline Yalıpark Otel & 4 Yıldızlı & Ortahisar & 88 & 176 \\
\hline Yol İş Holiday Otel Trabzon & 4 Yıldızlı & Ortahisar & 65 & 130 \\
\hline Zarha Mountain Resort Hotel & 4 Yıldızlı & Sürmene & 61 & 126 \\
\hline Park Dedeman Trabzon & 4 Yıldızlı & Yomra & 149 & 346 \\
\hline Emir Grand Hotel \& Spa (Aurum) & 4 Yıldızlı & Yomra & 135 & 270 \\
\hline Trabzon Nov Otel & 4 Yıldızlı & Yomra & 200 & 400 \\
\hline Doubletree By Hilton Trabzon & 5 Yıldızlı & Akçaabat & 190 & 382 \\
\hline Radisson Blu Hotel Trabzon & 5 Yıldızlı & Ortahisar & 163 & 326 \\
\hline Ramada Plaza Trabzon Hotel \& Spa & 5 Yıldızlı & Ortahisar & 350 & 704 \\
\hline Zorlu Grand Hotel & 5 Yıldızlı & Ortahisar & 157 & 335 \\
\hline TOPLAM & & & $\mathbf{2 2 5 9}$ & 4624 \\
\hline Kayna & & & \\
\hline
\end{tabular}

Kaynak: (trabzon.ktb.gov.tr) ve (www.turob.com)'dan alınan bilgiler derlenerek oluşturulmuştur.

Tabloda 1'de görüldüğü üzere Trabzon ilinde 16 adet 4 yıldızlı ve 4 adet de 5 yıldızlı otel bulunmaktadır. Çalışmanın nicel ve nitel olarak iki ayağı bulunmaktadır. Bunlardan ilki; Brotherton ve Shaw'ın (1996) çalışmaları sonucunda ortaya çıkarılan Kritik Başarı Faktörlerinin Trabzon ilindeki 4 ve 5 yıldızlı otel yöneticileri tarafından değerlendirilmesidir. Bu faktörler işletme içi kritik başarı faktörleri olup 9 ayrı bölüme ayrılmış toplam 46 ifadeden oluşmaktadır. Anket formu 5'li Likert Ölçeğine göre hazırlanmıştır. 1= "Hiç Önemli Değil" ve 5 ise; "Çok Önemli" olarak belirtilmiş ve 1'den 5'e kadar katılımcllara uygun düşen noktanın işaretlenmesi istenmiştir. Anket formu internet üzerinden hazırlanmış ve otel yöneticilerin tamamına (tepe yöneticiler, önbüro ve satış-pazarlama müdürleri) link olarak gönderilip doldurulması istenmiştir. 46 gönderiden 19 geri dönüş olmuştur. Geri dönüş yapanların az olmasının sebebi pandemi sebebiyle ile bazı otellerin hali hazırda kapalı olmasıdır. Elde edilen veriler tablolaştırılıp yorumlanmıştır.

Çalışmanın ikinci ayağı yani nitel kısmı ise; Trabzon ilindeki 4 ve 5 yıldızlı otellerin tepe yöneticileri ile görüşülerek gerçekleştirilmiştir. Çalışmanın örneklemi olarak Trabzon' daki tüm 4 ve 5 Yıldızlı oteller dahil edilmekle beraber pandemi dönemi sebebiyle bazı otellerin hali hazırda kapalı olması, bazı otel yöneticilerinin de görüşmeyi kabul etmemesi sebebiyle 10 otel yöneticisi 
ile yüz yüze görüşme sağlanmıştır. Görüşmecilere konu anlatılmış ve konu hakkındaki düşüncelerini dile getirmeleri istenmiştir. Bunun için önceden bir soru formu hazırlanmamıştır. Yani; mülakat türlerinden biçimsel olmayan mülakat tekniği kullanılmıştır. Altunışık vd.,'e göre (2010:92) biçimsel olmayan mülakatlar; genel bir alanda var olan bilgiyi açığa çıkarmak üzere yapılır. Bu tür mülakatlarda önceden hazırlanmış soru seti yoktur fakat mülakatı yapan kişi tartışılan konunun hangi boyutlarını ortaya çıkarmaya çalıştığını bilmek ve mülakatı o zemin üzerinde yürütmek durumundadır. Cevaplayıcılar ise belirlenmiş konu hakkında görüşlerini belli bir kalıba oturtmadan ifade etmektedir.

Biçimsel olmayan mülakat tekniğinin seçilmesinin bir sebebi de KBF yönteminin öncülerinden Rockart (1979)'ın, faktörlerin tespiti için yöneticilerle açık-uçlu mülakat yönetimini önermesidir. Auruskeviciene vd.,'ne göre (2006:333) de; Kritik Başarı Faktörlerinin belirlenmesinde kullanılabilecek bir araştırma yöntemi olarak genel kabul görmüş bir yöntem yoktur. Katılımcıların konu hakkındaki görüşlerini sorularla kısıtlanmadan özgürce dile getirmeleri amaçlanmıştır. Haziran 2020- Temmuz 2020 tarihleri arasında yapılan görüşmelerin öncesinde örneklem içerisine dahil edilen tüm otel tepe yöneticileri aranarak randevu talep edilmiştir. Kabul eden yöneticiler ile kendi ofislerinde yüz yüze görüşülmüştür. Tüm görüşmelerin ortalaması alındığında her görüşme ortalama 11 dakika 07 saniye olarak gerçekleşmiştir. Görüşme sırasında izin alınarak ses kaydı alınmış ve görüşme sonrası yazıya dökülmüştür. Katılımcların hepsi çalıştıkları otellerin tepe yöneticileri olduğu için deşifre etmemek adına otel isimleri verilmemiştir. Çalışma boyunca her bir katılımc1, atanan kodlarla anılacaktır (K1, K2, ... K10). Elde edilen veriler MAXQDA-2020 programı aracilığıyla analiz edilmiştir.

\section{BULGULAR}

Araştırmanın ilk adımında anket formu üzerinden Trabzon İlindeki 4 ve 5 yıldızlı otellerin yöneticilerinin işletme içerisindeki kritik başarı faktörlerini değerlendirmeleri amacıyla 9 ayrı bölümde 46 ifade yöneltilerek sayısal değerlendirmeler elde edilmiştir. İfadeler; ortalamaları ve standart sapmaları ile birlikte frekans tablosunda verilmiştir:

Tablo 2. Otel Yöneticilerinin İşletme İçerisindeki Kritik Başarı Faktörleri ile İlgili Görüşleri

\begin{tabular}{|c|c|c|c|c|}
\hline \multirow{2}{*}{ 1. En Kritik Ön Büro KBF'leri } & \multicolumn{2}{|c|}{ n } & \multirow{2}{*}{ Ortalama } & \multirow{2}{*}{ Std. Sapma } \\
\hline & Geçerli & Kayıp & & \\
\hline Doğru ve Verimli Rezervasyon Sisteminin İşletilmesi & 19 & 0 & 4,8421 & 0,37463 \\
\hline Etkili Personel Satış Becerileri & 19 & 0 & 4,7368 & 0,73349 \\
\hline Yüksek Seviyede Müşteri Hizmetleri Sağlama & 19 & 0 & 4,947 & 0,2294 \\
\hline Doluluk Oraninin Maksimizasyonu & 19 & 0 & 4,737 & 0,6534 \\
\hline Uygun Personel Tutumlarının Geliştirilmesi & 19 & 0 & 4,895 & 0,3153 \\
\hline Etkili Gelir Yönetimi & 19 & 0 & 4,947 & 0,2294 \\
\hline \multirow{2}{*}{ 2. En Kritik Yiyecek ve İçecek Servisi KBF'leri } & \multicolumn{2}{|c|}{$\mathbf{n}$} & \multirow{2}{*}{ Ortalama } & \multirow{2}{*}{ Std. Sapma } \\
\hline & Geçerli & Kayıp & & \\
\hline Üst Düzey Hizmet Sunumu & 19 & 0 & 4,947 & 0,2294 \\
\hline Müşteri Hizmetlerinin Geliştirilmesi & 19 & 0 & 4,895 & 0,3153 \\
\hline Personel Becerilerini Üst Düzey Geliştirme ve Sürdürme & 19 & 0 & 5 & 0 \\
\hline $\begin{array}{l}\text { Uygun Personel Tutumlarının ve Görünüşünün } \\
\text { Sağlanması }\end{array}$ & 19 & 0 & 5 & 0 \\
\hline Ambiyans ve Çevre Kalitesinin Sağlanması & 19 & 0 & 4,895 & 0,3153 \\
\hline Yiyecek ve İçecek Sunum Kalitesinin Artırılması & 19 & 0 & 5 & 0 \\
\hline Yüksek Kaliteli Yiyecek ve İçecek Ürünleri Üretmek & 19 & 0 & 4,842 & 0,3746 \\
\hline \multirow{2}{*}{ 3.En Kritik Yiyecek ve İçecek Üretimi KBF'leri } & \multicolumn{2}{|c|}{$\mathbf{n}$} & \multirow{2}{*}{ Ortalama } & \multirow{2}{*}{ Std. Sapma } \\
\hline & Geçerli & Kayıp & & \\
\hline
\end{tabular}




\begin{tabular}{|c|c|c|c|c|}
\hline Tutarlı/İstikrarlı Kalitede Gıda Üretimi & 19 & 0 & 4,842 & 0,3746 \\
\hline Uygun Standartların ve Prosedürlerin Kurulması & 19 & 0 & 4,895 & 0,3153 \\
\hline $\begin{array}{l}\text { Tedarikçilerle Etkin Satın Alma Uyg. ve Etkili İrtibatın } \\
\text { Sağlanması }\end{array}$ & 19 & 0 & 4,895 & 0,3153 \\
\hline Minimum Gıda İsrafını Sağlamak & 19 & 0 & 4,684 & 0,4776 \\
\hline Verimli Üretim Yöntemlerinin Kullanımı & 19 & 0 & 5,000 & 0,0000 \\
\hline Yüksek Hijyen Standartlarını Sürdürmek/Korumak & 19 & 0 & 4,895 & 0,4588 \\
\hline \multirow{2}{*}{ 4. En Kritik Kongre ve Ziyafet KBF'leri } & \multicolumn{2}{|c|}{$\mathbf{n}$} & \multirow{2}{*}{ Ortalama } & \multirow{2}{*}{ Std. Sapma } \\
\hline & Geçerli & Kayıр & & \\
\hline Fiyatların Rekabetçi Olacak Şekilde Düzenlenmesi & 19 & 0 & 4,789 & 0,4189 \\
\hline Yüksek Kaliteli Yiyecek ve İçecek Üretimi & 19 & 0 & 4,895 & 0,3153 \\
\hline Esnek Olanaklar Sağlama & 19 & 0 & 4,579 & 0,6070 \\
\hline Mümkün Olan Her Yerde Satış Yapmak & 19 & 0 & 4,737 & 0,4524 \\
\hline Detaylara ve Özel Müşteri Gereksinimlerine Dikkat Etmek & 19 & 0 & 4,842 & 0,3746 \\
\hline \multirow{2}{*}{ 5. En Kritik Tatil/Eğlence Operasyonları KBF'leri } & \multicolumn{2}{|c|}{$\mathbf{n}$} & \multirow{2}{*}{ Ortalama } & \multirow{2}{*}{ Std. Sapma } \\
\hline & Geçerli & Kayıр & & \\
\hline Tesis Kalitesinin Üst Düzeyde Olması & 19 & 0 & 4,842 & 0,3746 \\
\hline Uygun Tesis Yelpazesi/Seçeneği Sunmak & 19 & 0 & 4,789 & 0,4189 \\
\hline Üyelik Düzeylerinin Korunması/Sürdürülmesi & 19 & 0 & 4,211 & 1,0317 \\
\hline Tesislerin Çekiciliğinin Geliştirilmesi & 19 & 0 & 4,737 & 0,4524 \\
\hline Yüksek Kaliteli Personel Sağlamak & 19 & 0 & 4,842 & 0,3746 \\
\hline Üst Düzey Temizlik ve Hijyenin Sağlanması & 19 & 0 & 4,632 & 0,5973 \\
\hline \multirow{2}{*}{ 6. En Kritik Arka Plan Departmanların KBF'leri } & \multicolumn{2}{|c|}{$\mathbf{n}$} & \multirow{2}{*}{ Ortalama } & \multirow{2}{*}{ Std. Sapma } \\
\hline & Geçerli & Kayıp & & \\
\hline Etkili Temizlik Programları Operasyonu & 19 & 0 & 4,789 & 0,4189 \\
\hline Etkili Güvenlik Sistemlerinin Sağlanması & 19 & 0 & 4,895 & 0,4588 \\
\hline Etkili Bir Çamaşırhane Sisteminin Muhafaza Edilmesi & 19 & 0 & 4,526 & 0,9643 \\
\hline Departmanlar Arası Etkin İrtibatın Sağlanması & 19 & 0 & 5,000 & 0,0000 \\
\hline \multirow{2}{*}{ 7. En Kritik Satış ve Pazarlama KBF'leri } & \multicolumn{2}{|c|}{$\mathbf{n}$} & \multirow{2}{*}{ Ortalama } & \multirow{2}{*}{ Std. Sapma } \\
\hline & Geçerli & Kayıp & & \\
\hline Pazar Payının Muhafaza Edilmesi & 19 & 0 & 4,789 & 0,4189 \\
\hline İyi Eğitimli Satış Ekibinin Geliştirilmesi & 19 & 0 & 5,000 & 0,0000 \\
\hline Etkili Reklam Sağlama & 19 & 0 & 4,789 & 0,4189 \\
\hline Etkili Bir Pazar Hakkında Bilgi Toplama Operasyonu & 19 & 0 & 4,632 & 0,6840 \\
\hline Etkili Bir Müşteri Veri Tabanının Muhafaza Edilmesi & 19 & 0 & 4,684 & 0,4776 \\
\hline Etkili Rakip İstihbaratı Sağlanması & 19 & 0 & 4,737 & 0,4524 \\
\hline \multirow{2}{*}{ 8. En Kritik İnsan Kaynakları Yönetimi KBF'leri } & \multicolumn{2}{|c|}{$\mathbf{n}$} & \multirow{2}{*}{ Ortalama } & \multirow{2}{*}{ Std. Sapma } \\
\hline & Geçerli & Kayıр & & \\
\hline Etkin İşe Alma ve Seçim Prosedürlerinin Operasyonu & 19 & 0 & 4,789 & 0,4189 \\
\hline Tüm Personel İçin Düzenli Eğitim Verilmesi & 19 & 0 & 4,842 & 0,3746 \\
\hline Personel Moral/Tutum ve Sadakatinin Korunması & 19 & 0 & 4,737 & 0,6534 \\
\hline Personel Devir Hızı Oranının Azaltılması & 19 & 0 & 4,474 & 0,6967 \\
\hline Uygun Personel Değerlemesi Yapmak & 19 & 0 & 4,579 & 0,6925 \\
\hline Etkili Personel Geliştirmenin Sağlanması & 19 & 0 & 4,684 & 0,4776 \\
\hline \multirow{2}{*}{ 9. Turistlerin Konaklamalarında En Kritik KBF'ler } & $\mathbf{n}$ & & Ortalama & Std Sapma \\
\hline & Geçerli & Kayıp & Urtalama & \\
\hline Kalitenin İstikrarı & 19 & 0 & 4,895 & 0,3153 \\
\hline Yüksek Temizlik Kalitesi & 19 & 0 & 4,632 & 0,5973 \\
\hline Müşteri İhtiyaçlarının Karşılanması & 19 & 0 & 4,947 & 0,2294 \\
\hline Uygun Eğitim Programlarının Uygulanması & 19 & 0 & 4,684 & 0,4776 \\
\hline Maliyetleri En Aza İndirme & 19 & 0 & 4,632 & 0,5973 \\
\hline Oda Tiplerindeki Çeşitlilik & 19 & 0 & 4,474 & 0,6967 \\
\hline
\end{tabular}


Tablo 2' de yöneticiler tarafından 1'den 5'e kadar önem derecesine göre işaretledikleri kritik başarı faktörleri toplu halde görülmektedir. Tabloda da görüldüğü üzere tüm yöneticiler bu ifadelere yüksek oranda katılmaktadır yani; tüm ifadelerin ortalaması 4 'ün üzerindedir. Bunların içerisinde daha fazla katıldıkları ifadeleri tek tek inceleyecek olursak; 1 . Bölümde yani; En kritik ön büro KBF'ninin sıralandığı bölümde "Yüksek seviyede müşteri hizmetleri sağlama" ve "Etkili Gelir Yönetimi" ifadeleri en yüksek ortalamayı almıştır (her ikisi de 4,94). 2. Bölümde (En Kritik Yiyecek ve İçecek Servisi KBF’leri) özellikle 3 ifade tüm katılımcılar tarafından en önemli faktörler olarak görülmüştür yani, 5 tam puan almışlardır. Bunlar; "Müşteri Hizmetlerinin Geliştirilmesi", "Personel Becerilerini Üst Düzey Geliştirme ve Sürdürme" ve "Yiyecek ve İçecek Sunum kalitesinin artırılması" ifadeleridir. 3. Bölümde (En Kritik yiyecek ve içecek üretimi KBF'leri), "Verimli Üretim Yöntemlerinin Kullanımı" tüm katılımcılar tarafından en önemli faktör olarak belirlenmiştir (5 tam puan). 4. Bölümde (En Kritik kongre ve ziyafet KBF'leri), "Fiyatların Rekabetçi olacak şekilde düzenlenmesi" ve "Yüksek Kaliteli Yiyecek ve İçecek Üretimi" ifadeleri en önemli görülen ifadelerdir (ikisi de ortalama 4,88). 5. Bölümde (En Kritik tatil/eğlence operasyonları KBF'leri), “Tesis Kalitesinin Üst Düzeyde olması" ve "Yüksek Kaliteli Personel Sağlamak" ifadeleri (4,81 ortalama) en yüksek puanı almıştır. 6. Bölümde (En Kritik Arka Plan Departmanların KBF'leri), "Departmanlar Arası Etkin İrtibatın Sağlanması" tüm yöneticiler tarafından en yüksek puan verilerek ( 5 tam puan) en önemli faktör olarak belirtilmiştir. 7 . Bölümde (En kritik satış ve pazarlama KBF'leri), "İyi Eğitimli Satış Ekibinin Geliştirilmesi” ifadesi 5 tam puan alarak en yüksek önemdedir. 8. Bölümde ise (En kritik insan kaynakları yönetimi KBF'leri), “Tüm Personel için Düzenli Eğitim Verilmesi” ifadesi en önemlisi görülmüştür (ortalama 4,81). 9. Bölümde (Turistlerin Konaklamalarında En Kritik KBF'ler), “Müşteri İhtiyaçlarının Karşılanması" en yüksek oranda (ortalama 4,94) önem verilen faktör olmuştur.

Tablo 2'ye bakıldığında genel olarak tüm ifadelerin yüksek puanlar alması yani; önemli olarak görülmesinin yanında yukarıda her bölüm için tek tek belirtilen ifadelerin öne çıtığ görülmektedir. Bunların ortak özelliği olarak; gelir ve fiyatlama, müşteri ihtiyaçlarını karşılamak için verilen hizmet, personel ve tesis özelliklerinin ön plana çıtı̆̆ı anlaşılmaktadır. Yöneticilerin otellerine gelen misafirlere verilen hizmetin kalitesine önem verdikleri ve otellerini yönetirlerken misafir ihtiyaçlarını göz önünde bulundurdukları söylenebilir. Bunun yanında işletmelerinin hizmet yoğun bir özelliği olan turizm endüstrisi içerisinde bulunduğunun farkındalığıyla misafire hizmeti sunan personelin kalitesinin hizmete de yansıyacağı düşüncesinde oldukları sonucu ortaya çıkabilir. Yöneticilerin, gelir yönetimi ve fiyatlamanın önemine de atıfta bulundukları gözlemlenmektedir. Bununla birlikte yöneticilerin; satışını yaptıkları hizmetin soyut olmasının yanında bunu destekleyen fiziksel unsurların da önemini es geçmedikleri görülmektedir.

Araştırmanın ikinci ayağı yani; nitel ayağında görüşmeyi kabul eden otel tepe yöneticileri ile mülakat yapılmıştır. Yapılan görüşmelerin analizleri sırasında literatürden ve görüşmeler esnasında oluşturulan ana temalar ve alt kodlar kod hiyerarşisi biçiminde Şekil 1'de verilmiştir. 


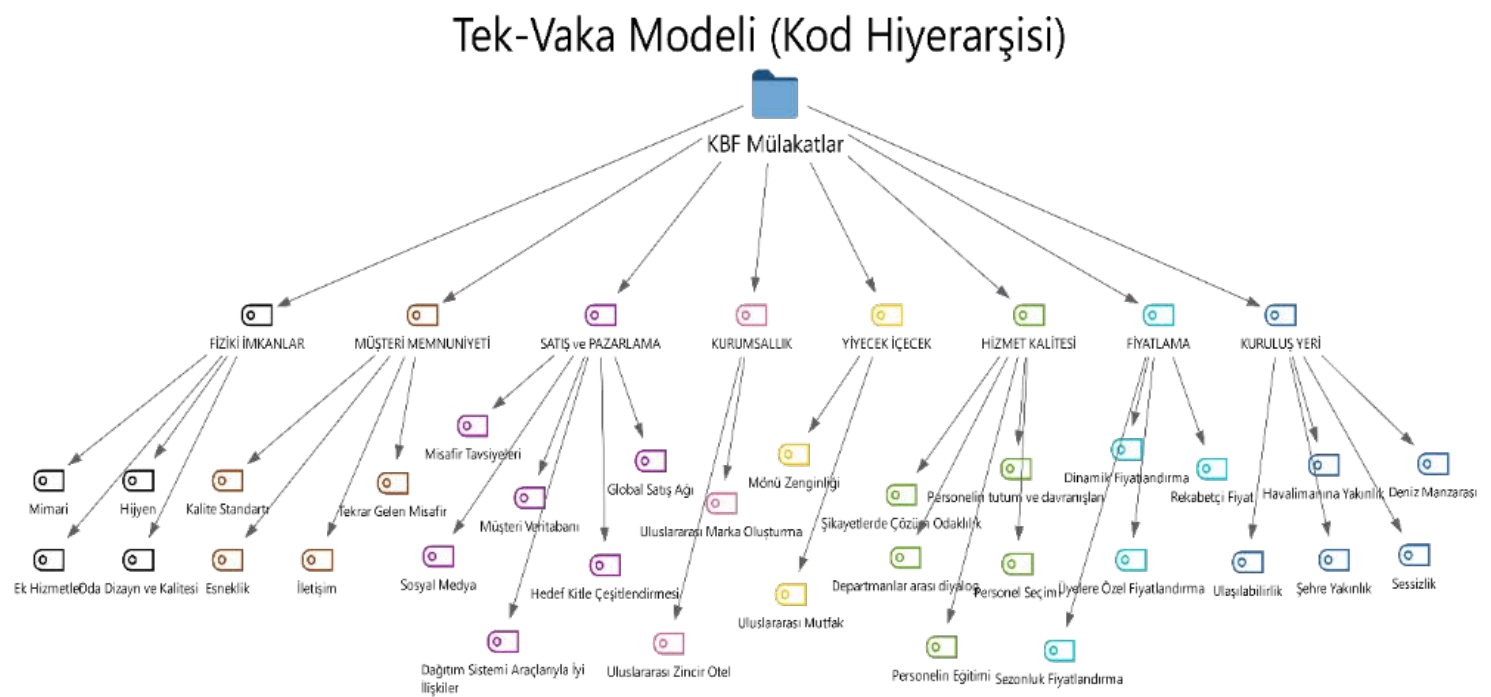

Şekil 1. Analizde Kullanılan Kodların Hiyerarşisi

Şekil 1'de de görüldügü üzere analiz 8 ana tema ve alt kodları vasıtası ile yapılmıştır. Her tema ayrı renkle temsil edilmiş ve temanın alt kodları için de aynı renk kullanılmıştır. Bununla birlikte oluşabilecek karmaşanın önüne geçilmek istenmiştir. Temalar ve alt kodları Tablo 3'te sıralanmıştır;

Tablo 3. Temalar ve Alt Kodları

\begin{tabular}{|c|c|c|}
\hline $\begin{array}{l}\text { 1. Kuruluş Yeri } \\
\text { Seçimi }\end{array}$ & $\begin{array}{l}\text { (1) Sessizlik } \\
\text { (2) Deniz Manzarası } \\
\text { (3) Şehre Yakınlık }\end{array}$ & $\begin{array}{l}\text { (4) Havalimanına Yakınlık } \\
\text { (5) Ulaşılabilirlik }\end{array}$ \\
\hline $\begin{array}{l}\text { 2. Fiyatlama } \\
\text { Politikası }\end{array}$ & \begin{tabular}{|l} 
(1) Rekabetçi Fiyat Sunma \\
(2) Üyelere Özel Fiyatlandırma
\end{tabular} & (3) Dinamik Fiyatlandırma \\
\hline 3. Hizmet Kalitesi & $\begin{array}{l}\text { (1) Personel Seçimi } \\
\text { (2) Personelin Eğitimi } \\
\text { (3) Personelin Tutum ve Davranışları }\end{array}$ & $\begin{array}{l}\text { (4) Departmanlar Arası Diyalog } \\
\text { (5) Şikayetlerde Çözüm } \\
\text { Odaklılık }\end{array}$ \\
\hline $\begin{array}{l}\text { 4. Yiyecek-İçecek } \\
\text { Hizmeti }\end{array}$ & $\begin{array}{l}\text { (1) Yöresel Mutfak } \\
\text { (2) Uluslararası Mutfak }\end{array}$ & (3) Mönü Zenginliği \\
\hline 5. Kurumsallık & (1) Uluslararası Zincir Otel Olma & $\begin{array}{l}\text { (2) Uluslararası Marka } \\
\text { Oluşturma }\end{array}$ \\
\hline $\begin{array}{l}\text { 6. Satış ve } \\
\text { Pazarlama Araçları }\end{array}$ & $\begin{array}{l}\text { (1) Global Satış Ağı } \\
\text { (2) Dağıtım Sistemi Araçlarıyla İyi } \\
\text { İlişkiler } \\
\text { (3) Merkezi Rezervasyon Sistemi } \\
\text { (4) Müşteri Veri Tabanı }\end{array}$ & $\begin{array}{l}\text { (5) Online Satış Platformları } \\
\text { (6) Hedef Kitle Çeşitlendirmesi } \\
\text { (7) Sosyal Medya } \\
\text { (8) Misafir Tavsiyeleri }\end{array}$ \\
\hline $\begin{array}{l}\text { 7. Müşteri } \\
\text { Memnuniyeti }\end{array}$ & $\begin{array}{l}\text { (1) İletişim } \\
\text { (2) Tekrar Gelen Misafir (Repeat } \\
\text { Guest) }\end{array}$ & (3) Esneklik \\
\hline $\begin{array}{l}\text { 8. Otelin Fiziki } \\
\text { İmkanları }\end{array}$ & $\begin{array}{l}\text { (1) Odanın Dizaynı ve Kalitesi } \\
\text { (2) Hijyen }\end{array}$ & $\begin{array}{l}\text { (3) Otel İçerisindeki Aktiviteler } \\
\text { (4) Ek Hizmetler (Dışarıdan da } \\
\text { Misafirin Kabul Edildiği Ek } \\
\text { Kazanç Sağlayan Hizmetler) }\end{array}$ \\
\hline
\end{tabular}


Tablo 3'teki temalar ve onları oluşturan alt kodlar görüşme sırasında katılımcıların beyan ettikleri fikirler ve literatür taraması sonucu oluşturulmuştur. Yapılan tüm analizler de bu kod hiyerarşisi aracılığıyla yapılmıştır. Temalar ve kodların dağılımı Şekil 2'de verilmiştir.

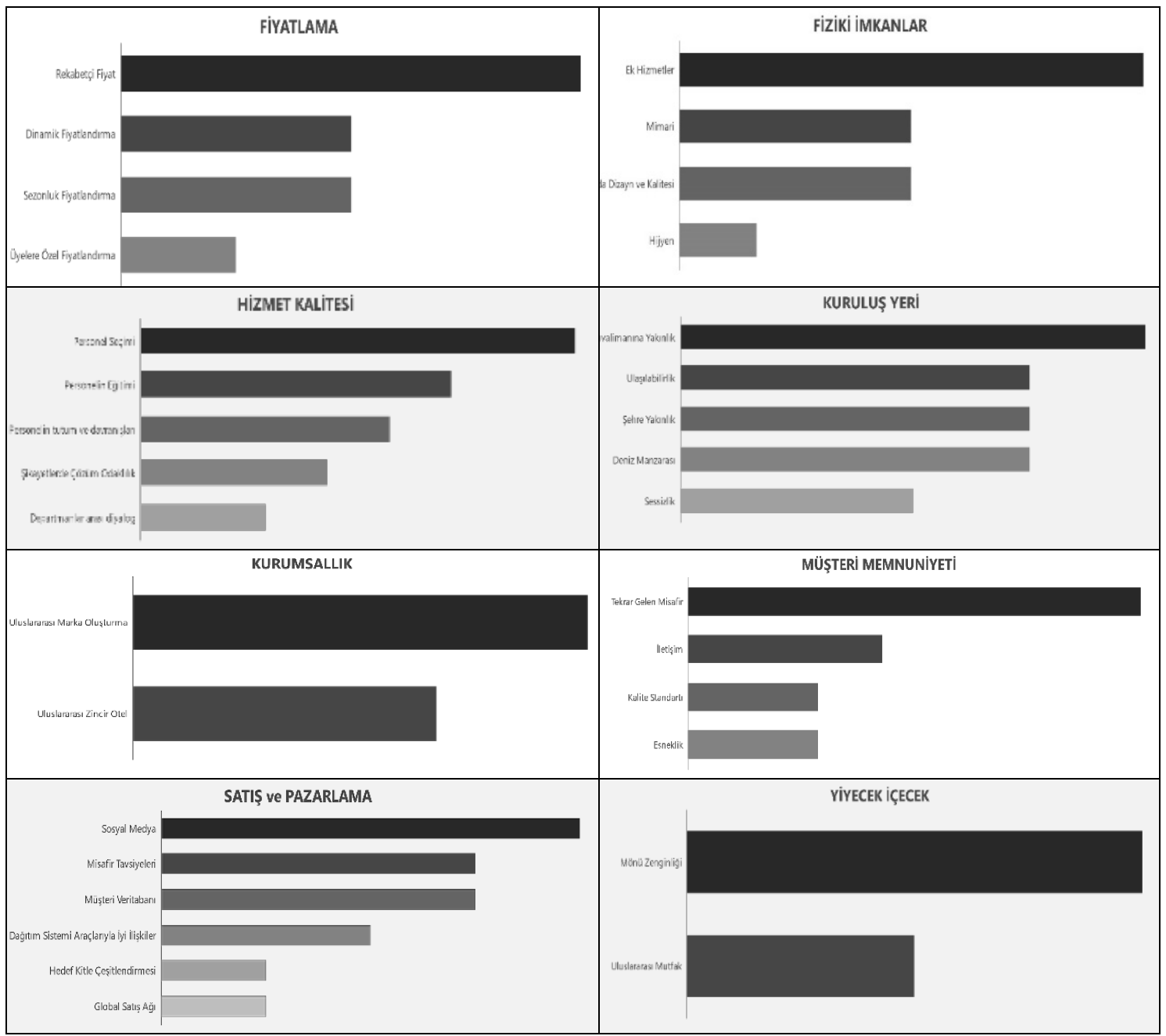

Şekil 2. Alt Kodların İstatistiği

Şekil 2'de Temalara ait alt kodların görüşmeler boyunca ne kadar sıklıkla belirtildiği görülmektedir. Buna göre fiyatlama konusunda katılımcıların görüşleri "rekabetçi fiyatlama stratejisini" belirlemelerinin KBF arasında olduğunu göstermektedir. Fiziki imkanlar konusunda ise ek gelir getirici, tesis olanaklarını zenginleştirici "ek hizmetlerin" KBF olarak görüldüğü anlaşılmaktadır. Hizmet kalitesi açısından bakıldığında ise "Personel Seçimi"nin en önemli KBF olduğu belirtilmiştir. Kuruluş yeri seçiminde ise; "havalimanına yakınlı" faktörünün önemi görülmektedir. Müşteri memnuniyeti konusunda ise en önemli KBF'nin “Tekrar Gelen Misafir" olduğu ve bunun müşteri memnuniyetinin de bir ispatı olduğu görülmektedir. "Sosyal Medya" en önemli Satış ve Pazarlama KBF'si olarak belirtilmiştir. Yiyecek-içecek temasında ise "Mönü Zenginliği" nin en önemli KBF olduğu belirlenmiştir.

Görüşmeler sırasında katılımcıların kullanmayı tercih ettikleri sözcüklerin analizi sonucu elde edilen kelime bulutu Şekil 3'te verilmiştir. 


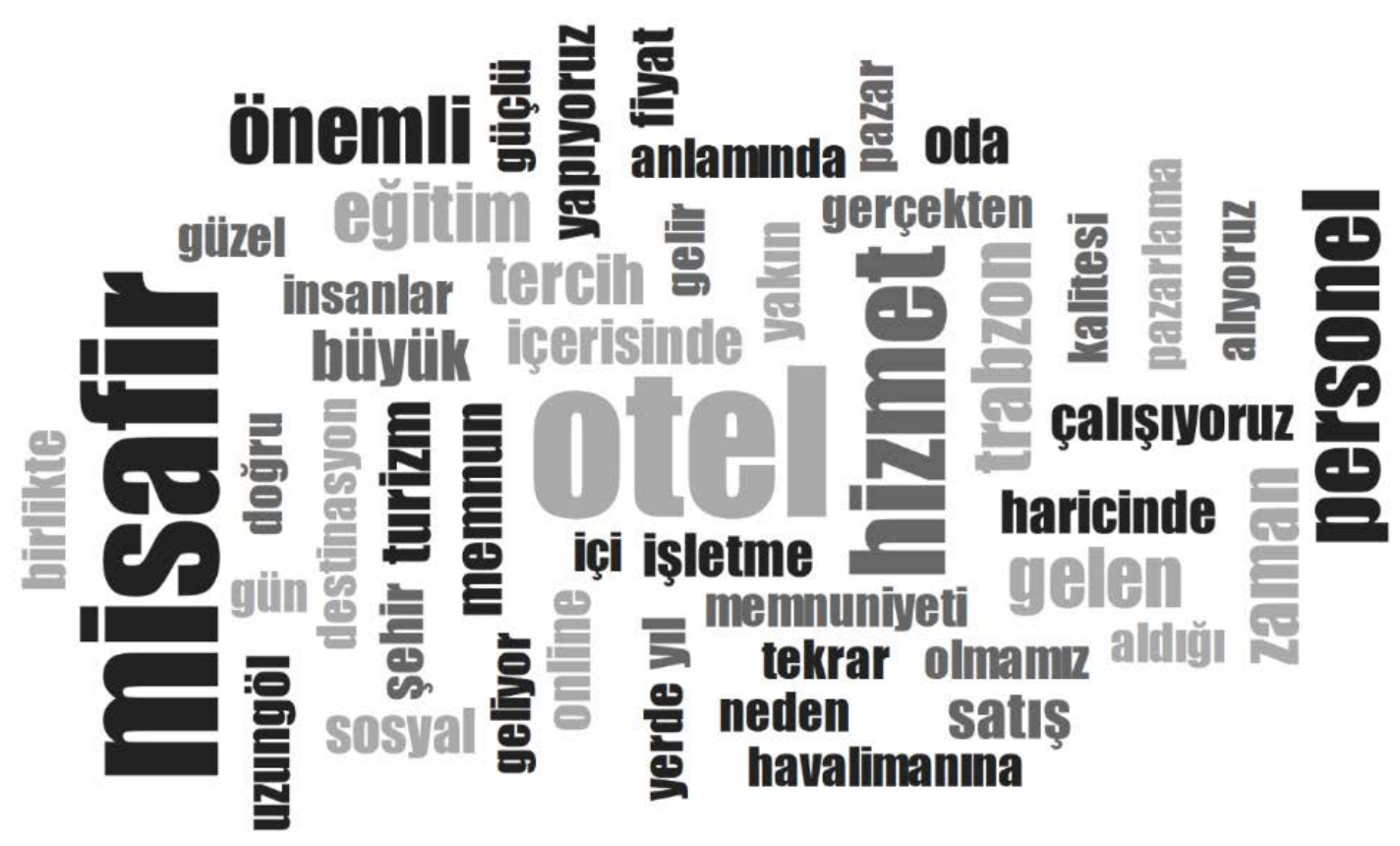

Şekil 3. Katılımcıların Verdikleri Cevaplara Göre Oluşturulan Kelime Bulutu

Kelime bulutu oluşturulurken bağlaçlar, edatlar vs. hariç tutulmuştur. Ayrıca; bazı kelimeler birleştirilmiştir. Örneğin; "otel" kelimesi, "oteli", "otele", "otelde" gibi kelimelerle birleştirilip kelime bulutuna dahil edilmiştir. Kelime bulutunda daha büyük yazılan kelimeler daha fazla vuruş alan kelimelerdir. Kelime bulutuna bakıldığında katılımcıların çalışmanın konusu hakkında neler düşündüklerinin ipuçları görülebilir. "Hizmet", "misafir", "personel" gibi kelimelerin daha fazla vuruş alması katılımcıların misafirlere verdikleri hizmeti de bu hizmeti veren personeli de aynı oranda önemsedikleri yorumu yapılabilir.

\section{Tek-Vaka Modeli}

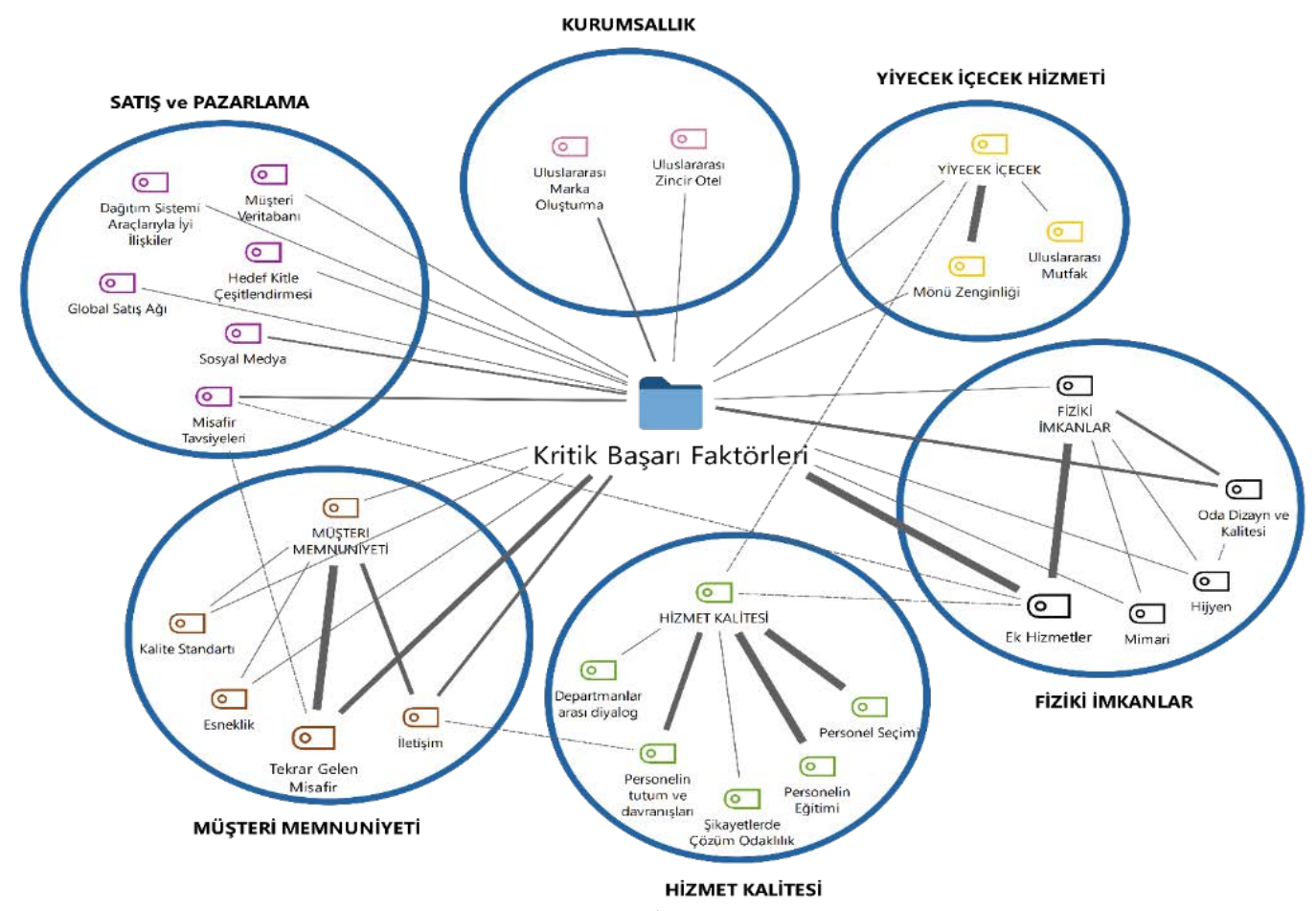

Şekil 4. Kritik Başarı Faktörleri: Tüm Karşılıklı İlişkiler - Bütünsel Bakış 
Şekil 4'te temalar ve kodlar arasındaki ilişkiler bütünsel olarak verilmiştir. Aralarındaki karşılıklı ilişkiler ise çekilen çizgilerle anlatılmıştır. Doğrudan çizgiler direkt karşılıklı ilişkileri, kesikli çizgiler ise dolaylı ilişkileri göstermektedir. Çizgilerin kalınlığı ise ilişkinin şiddetini anlatmaktadır. Katılımcılarla yapılan görüşmelerin analizi sonunda oluşturulan bu ilişki haritasına bakıldığında; katılımcılar tesisleri açısından en kritik gördükleri başarı faktörlerinin başında konaklama gelirleri haricinde gelir getirici, işletmenin çekiciliğini de artırabilecek aynı zamanda tesislerde konaklayan misafirler haricinde de kullanımı sağlanabilecek ek hizmetlerin geldiği görülmektedir (Ek hizmetler kodu). Bu unsurun Hizmet kalitesi ve misafir tavsiyeleri ile dolaylı ilişkisi olduğu da saptanmıştır. Tesis içerisinde sunulan ek hizmetlerin misafir tavsiyelerine de etkisi olduğu ve ayrıca, hizmet kalitesini de artırdığı yorumu yapılabilir. Ayrıca; "Ek Hizmetler" kodu modelde direkt ve kalın çizgiyle gösterildiği üzere "Fiziki İmkanlar" temasının en önemli unsurunu oluşturmaktadır. Diğer şiddetli ilişkiye bakıldığında "Tekrar Gelen Misafir" kodu öne çıkmaktadır. Daha önce otelin hizmetlerini almış misafirin tekrar aynı oteli tercih etmesi katılımcılar tarafından kritik başarı faktörü olarak görülmektedir. Bu durum modelde de görüldüğü üzere müşteri memnuniyetini direkt olarak sağlayan en önemli unsur olarak da belirtilmektedir. Tekrar gelen misafirin, misafir tavsiyeleri üzerinde de dolaylı bir ilişkisi olduğu modele yansımıştır.

Misafirin konakladığı odaların tasarımı ve kalitesinin KBF arasında önemli bir yer aldığı yine modelde görülmektedir. Odaların dizayn ve kalitesinin hijyen ile dolaylı bir ilişkisinin ortaya çıkması doğal olarak görülmektedir. Odaların temizliğinin de kalitesini etkileyen bir unsur olduğu görülmektedir. Ayrıca; tesisin fiziki imkanlarını oluşturan önemli unsurlardan biri olduğu da model aracılığıyla görülmektedir.

İletişim de KBF arasında yer alan unsurlardan biridir. Misafirin personel ile iletişimini belirten "İletişim" kodu müşteri memnuniyetinin sağlanmasında önemli etkenlerden biri olarak gösterilmiştir. Ayrıca, Personelin tutum ve davranışları ile dolaylı bir ilişkisi olduğu da modelde kesik çizgilerle gösterilmiştir.

"Satış ve Pazarlama" teması altındaki kodların birçoğunun katılımcılar açısından KBF içerisinde gösterildiği görülmekle beraber "Misafir Tavsiyeleri" ve "Sosyal Medya" kodları bir tık daha önemli olarak gösterilmiştir. Misafir tavsiyelerinin tekrar gelen misafirlerle ve otelde sunulan ek hizmetlerle dolaylı ilişkisinin olduğu da görülmektedir.

Katılımcıların bir kısmı uluslararası zincir otel yöneticisi bir kısmı da Trabzon'da bulunan yerel otel yöneticileridir. Zincir otellerin yönetimi ile yerel otellerin yönetiminin farklllıklar gösterebileceği düşüncesiyle katılımcılar ayrılmış, aralarında ortak fikirler ve ayrıştıkları noktalar belirlenmek istenmiştir. Bu amaç doğrultusunda Şekil 5 oluşturulmuştur. 


\section{İki-Vaka Modeli}
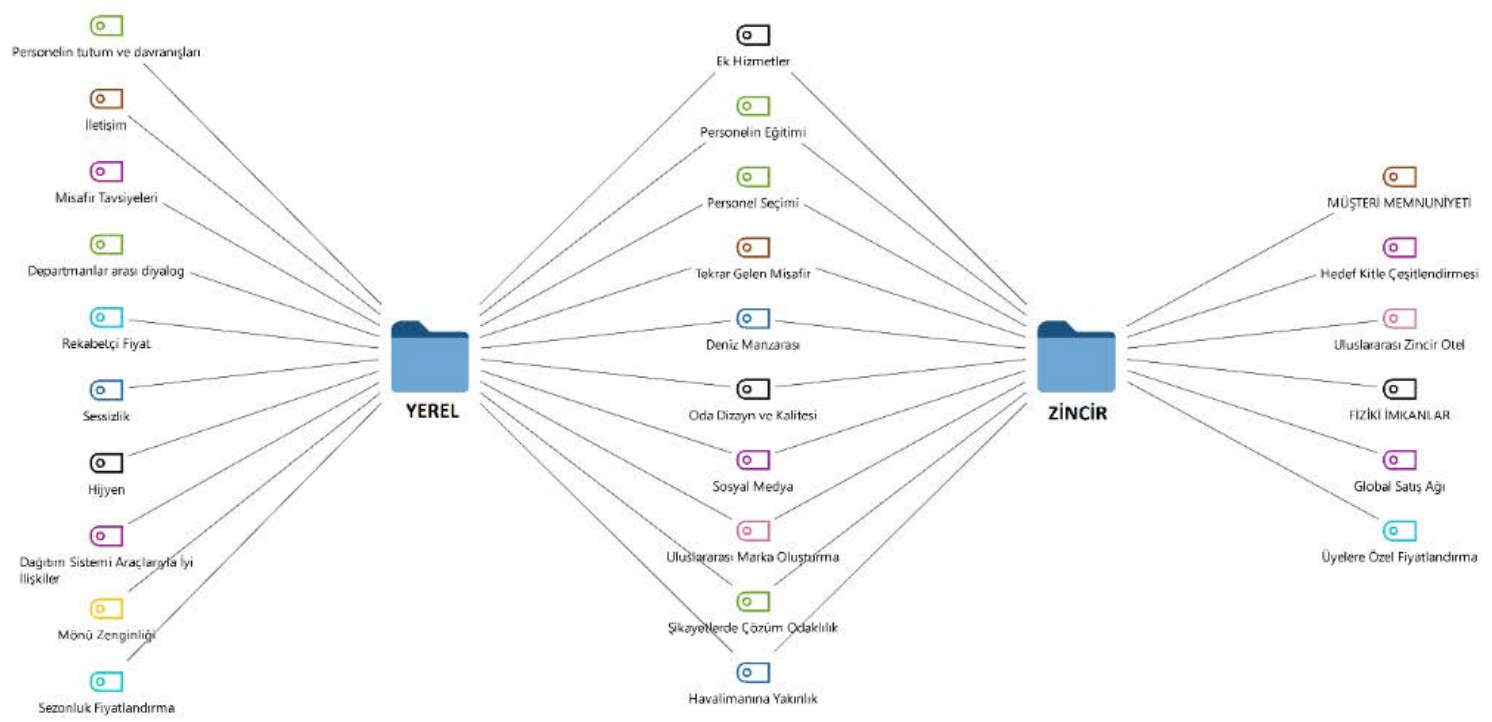

Şekil 5. Zincir Otel ve Yerel Otellerin Karşılaştırıldı̆̆ İki Vaka Modeli

Tablo 5'te Trabzon'daki uluslararası zincir otel yöneticileri ile Yerel otel yöneticilerinin görüşlerinin karşılaştırılmıştır. Soldaki kodlar yerel otel yöneticilerinin zincir otel yöneticilerinden ayrıştığı düşüncelerini, ortadaki kodlar yerel otel yöneticileri ile zincir otel yöneticilerinin ortak düşüncelerini ve sağdaki kodlar ise zincir otel yöneticilerinin yerel otel yöneticilerinden ayrışan düşüncelerini temsil etmektedir. Ortak kodlara bakıldığında ilginç bir kod göze çarpmaktadır. Bu da "Uluslararası Marka Oluşturma" kodudur. "Uluslararası Marka Oluşturma" kodunun yerel otel yöneticileri tarafından da vurgulanması, otellerinin uluslararası pazarda bir marka olma çabasını ve bunu kritik başarı faktörleri arasında gördüklerini anlatmaktadır. Yerel otel yöneticilerinin fiyatlamada rekabetçi fiyat uygularken zincir otellerin üyelik sistemine göre üyelere özel fiyatlandırma yaptıkları önemli bir ayrım olarak söylenebilir. Yerel otel yöneticilerinin, otellerinin satış ve pazarlaması için dağıtım kanalları ile iyi ilişkiler yürütmeyi önemsemesi ama bunun yanında zincir otel yöneticilerinin global satış ağlarını önemsemesi şu şekilde yorumlanabilir; uluslararası zincir otellerin merkezi rezervasyon sistemlerinin avantajını kullanmaktadır. Fakat yerel otellerde merkezi rezervasyon imkanı bulunmamaktadır. Bu sebeple, yerel oteller dağıtım kanallarına daha fazla ihtiyaç duymakta ve yerel otel yöneticileri de bu kanallarla iyi ilişkiler kurup otellerinin satışını artırmaya çabalamaktadır. Hem yerel otel yöneticilerinin hem de zincir otel yöneticilerinin personele verdiği önem de göze çarpmaktadır. Bunun yanında kuruluş yeri seçiminde her iki grubun da havalimanına yakınlığa önem vermesi de ilginç bir ayrıntıdır.

Hem nitel hem de nicel araştırmalar sonucu elde edilen verilerin analizin sonucunda katılımcıların otellerinin yönetiminde en önemli gördükleri KBF belirlenmiştir. Bu KBF sıralamak gerekirse; ek hizmetler (konaklama gelirleri haricinde gelir getirici, işletmenin çekiciliğini de artırabilecek aynı zamanda tesislerde konaklayan misafirler haricinde de kullanımı sağlanabilecek hizmetler), tekrar gelen misafir oranı, misafir ile iletişim, otel odalarının dizaynı ve kalitesi, misafir tavsiyeleri, uluslararası marka oluşturma ve işletmenin sosyal medyadaki etkinliğidir. Ortaya çıkan bu faktörler Trabzon ilindeki 4 ve 5 yıldızlı otellerin rekabet üstünlüğü sağlamak için önemli gördükleri konulardır. 


\section{TARTIŞMA, SONUÇ ve ÖNERILLER}

Bir destinasyonun başarıya ulaşmasında o destinasyonun konaklama imkanlarının önemli bir rol oynadığı gerçeği göz önünde bulundurulduğunda otel işletmelerinin rekabet ortamında başarılı olabilmesi için izleyecekleri yolların tespitinin önemi de anlaşılmaktadır. Bu maksatla yapılan çalışma sonucunda veriler aracilığı ile bulgulara ulaşılmıştır. Brotherton ve Shaw'ın (1996) çalışmaları sonucunda ortaya çıkarılan Kritik Başarı Faktörleri, (9 ayrı bölüme ayrılmış toplam 46 ifade) Trabzon ilindeki 4 ve 5 yıldızlı otel yöneticileri tarafından değerlendirilmiştir. Brotherton ve Shaw'ın ulaştı̆̆ sonuçlara paralel olarak ifadelerin hepsi yüksek oranda önemli çıkmıştır (5'li Likert ölçeğinde 4 üzerinde). Fakat 46 ifade içerisinde diğerlerine göre çok daha fazla önem duyulan ifadeler göze çarpmaktadır. Bunlar; "Yüksek Seviyede Müşteri Hizmetleri Sağlama", "Etkili Gelir Yönetimi” , "Müşteri Hizmetlerinin Geliştirilmesi”, "Personel Becerilerini Üst Düzey Geliştirme ve Sürdürme", "Yiyecek ve İçecek Sunum Kalitesinin Artırılması", "Verimli Üretim Yöntemlerinin Kullanımı", "Fiyatların Rekabetçi Olacak Şekilde Düzenlenmesi", "Yüksek Kaliteli Yiyecek ve İçecek Üretimi”, "Tesis Kalitesinin Üst Düzeyde Olması", "Yüksek Kaliteli Personel Sağlamak", "Departmanlar Arası Etkin İrtibatın Sağlanması”, "İyi Eğitimli Satış Ekibinin Geliştirilmesi”, "Tüm Personel İçin Düzenli Eğitim Verilmesi” ve "Müşteri İhtiyaçlarının Karşılanması" ifadeleridir. Bu ifadelerin diğerlerine nazaran daha yüksek çıkması Trabzon'daki otel yöneticilerinin kritik gördükleri başarı faktörleri hakkında bilgi vermektedir. Buna göre; otel yöneticilerinin otele gelen misafirlere verilen hizmet kalitesine ve misafir ihtiyaçlarına önem verdikleri anlaşılabilir. Bu faktörlere verilen önem, Davis ve Stone (1988), Çiçek Gökalp (2003), DiPietro, Parsa ve Gregory (2011), Abdullah ve Hamdan (2012) ve Albayrak (2014) çalışmalarında elde edilen sonuçlara paraleldir. Misafire verilen hizmetin kalitesini sağlayabilmek için bu hizmeti sunan personelin kalitesinin önemi de katılımcılar tarafından önemsendiği sonucu ortaya çıkmaktadır ve bu faktör, Davis ve Stone (1988) ve Dipietro vd., (2007)'lerinin çalışmalarında da ortaya konan sonuçlardan biridir. Hizmetin soyutluğunun yanında fiziksel unsurların da önemli olduğu yöneticiler tarafından belirtilmiştir. Fiziksel unsurların önemi bundan önceki araştırmacılar tarafından da vurgulanmıştır (Davis ve Stone, 1988; Çiçek Gökalp, 2003; Albayrak, 2014) Ayrıca yöneticiler gelir yönetimi ve fiyatlamanın da işletmeleri açısından önemli kritik başarı faktörlerinden olduğunu düşünmektedirler.

Trabzon'daki 4 ve 5 Yıldızlı otellerin tepe yöneticileri ile yapılan mülakatlar sonucu elde edilen veriler nitel analiz paket programı aracılığı ile analiz edilmiş ve ortaya çıan bulgular yorumlanmıştır. Bu bulgular ışığında şu sonuçlara ulaşılmaktadır: Katılımcıların görüşlerine göre otellerinin yönetimlerinde en önemli gördükleri KBF, konaklama gelirleri haricinde gelir getirici, işletmenin çekiciliğini de artırabilecek aynı zamanda tesislerde konaklayan misafirler haricinde de kullanımı sağlanabilecek ek hizmetler, gelen misafirler arasında tekrar gelen misafir oranının çokluğu, misafir ile iletişim, otel odalarının dizaynı ve kalitesi, misafir tavsiyeleri, uluslararası marka oluşturma ve işletmenin sosyal medyadaki etkinliğidir. Bu faktörler en fazla üzerinde durulan konulardır.

Trabzon'daki otel yöneticilerinin en önem verdiği konunun ek hizmetler olması, ilginç bir durumdur. Hem ek gelir getirmesi açısından hem de misafire sunulan olanakların çeşitliliği bakımından bir avantaj sağladığı düşünülen ek hizmetlerin bu denli önemli olması Trabzon'da yoğun turizm sezonunun düşük olması sebebiyle sezon dışı zamanda yöneticilerin tesislerini atıl kapasite ile çalıştırmak yerine farklı hizmetlerle ayakta tutmak istemeleri olabilir. Birçok araştırmada ve yapılan gözlemlerde Trabzon ilinin turizm sezonunun kısalı̆̆ından dolayı sorunlar yaşadığı görülmektedir. Görüşülen yöneticilerin bu problemi aşmak için çeşitli çabalar içerisinde oldukları gözlemlenmekle birlikte yapılan birçok yatırımın yılın büyük bölümünde atıl kalması sorunu işletmelerin tek başına aşacakları bir durum değildir. Kamu kurum ve 
kuruluşları, yerel ve merkezi yönetimlerin özel sektör ile devamlı iletişim halinde olarak mevcut durumu ortaya koyması, yaşanan bu sorunun ortak hareket ederek nasıl çözüme kavuşturabileceğinin belirlenmesi ve bu minvalde somut adımlar atılması elzemdir.

Katılımcların otellerine gelen misafirler arasında tekrar gelen misafir yani "repeat guest" oranının yüksekliğini ve bunun yanında misafir tavsiyelerini önemsemesi tesislerinde verdikleri hizmetin karşılı̆̆ı olarak görülmektedirler. Verilen hizmetin soyut olması, önceden deneme şansının olmaması, üretimle tüketimin eşzamanlı olması gibi özelliklerden dolayı kalitenin en etkili kanıtı bu hizmeti daha önce almış kişilerdir. Daha önce bu hizmeti alan misafirlerin tekrardan aynı hizmeti talep etmeleri ve çevresine de önermeleri bu bakımdan değerlidir. İşletmelerin tekrar gelen misafir oranını daha fazla artırma çabasına girmesi, sadakat programları, çeşitli üyelikler gibi programlarla özel promosyonlar sunması, misafir yorumlarının çeşitli sosyal medya kanalları da dahil olmak üzere daha fazla kişiye ulaşmasının sağlanması önerilmektedir. Bununla birlikte katılımcıların uluslararası marka oluşturmaya verdikleri önem de gerçekliğe dönüşebilir. Ayrıca; katılımcıların sosyal medyaya verdikleri önem sadece kendi tesislerinin reklamı amacıyla değil daha önce hizmetlerden faydalanmış misafirlerin etkinliği artırılarak da kullanılabilir.

Bundan sonra bu minvalde yapılacak çalışmalar için de öneriler şunlardır: Yöneticilerin yanında misafirlerin de Trabzon ilindeki otelleri tercih etmelerinde önemli gördükleri kritik faktörler incelenip yöneticilerinki ile karşılaştırılabilir. Zaman kısıtlılığı sebebiyle çalışma kapsamına alınamayan 3 yıldızlı otellerin de dahil edildiği bir çalışmayla kapsam genişletilebilir. Trabzon iline benzer özellikler taşıyan destinasyonlarda da araştırmalar yapılıp karşılaştırmalı analizlerle birlikte daha kapsamlı ve sonuçların daha fazla genelleştirilebileceği çalışmalar yapılabilir.

\section{KAYNAKÇA}

Abdullah, A.A. and Hamdan, M.H. (2012). Internal Success Factor of Hotel Occupancy Rate, International Journal of Business and Social Science, 3(22): 199-218.

Acar, D. ve Özçelik, H. (2011). Muhasebe Bilgi Kalitesini Etkileyen Kritik Başarı Faktörleri, Muhasebe ve Finansman Dergisi, (49): 10-23.

Albayrak, A. (2014). Müşterilerin Restoran Seçimlerini Etkileyen Faktörler: İstanbul Örneği, Anatolia: Turizm Araştırmaları Dergisi, 25(2): 190-201.

Altunışık, R., Coşkun, R., Bayraktaroğlu, S. ve Yıldırım, E. (2010). Sosyal Bilimlerde Araştırma Yöntemleri SPSS Uygulamalı (6. Baskı), Sakarya: Sakarya Yayıncllık.

Arsezen-Otamış, P. (2015). Fethiye'de TripAdvisor'a Kayıtlı Yiyecek İçecek İşletmeleri için Kritik Başarı Faktörleri ve Sosyal A $\breve{g}$ Analizi ile Performans Değerlendirmesi, Journal of Tourism and Gastronomy Studies, 3(2): 31-39.

Baker, M.J. and Cameron, E. (2007). Critical Success Factors in Destination Marketing, Tourism and Hospitality Research, 8(2): 79-97.

Barry, W.B. (1986), Strategic Planning Workbook for Public and Nonprofit Organizations, St. Paul: Amberst Wilder Foundation.

Brotherton, B and Shaw, J. (1996). Towards an identification and classification of Critical Success Factors in UK Hotels Pls, In.t J. Hospitality Management, 15(2): 113-135.

Bryson, J.M. (1995). Strategic Planning for Public and Nonprofit Organizations, San Fransisco: Jossey Publishers. 
Bullen, C.V. and Rockart, J.F. (1981). A Primer on Critical Success Factors, Center for Information Systems Research, Sloan School of Management, Massachusetts Institute of Technology, CISR No. 69, Sloan WP No. 1220-81.

Butler, T. and Fitzgerald, B. (1999). Unpacking the systems development process: an empirical application of the CSF concept in a research context, Journal of Strategic Information Systems, 8(4): 351-371.

Cooper, L. (2010). CSFs, KPIs, Metrics, Outcomes and Benefits, [Online] http://www.itsmsolutions. com/newsletters/DITYvol6iss5.pdf [Erişim Tarihi: 17.09.2019]

Çiçek Gökalp, E. (2003). Küçük Konaklama İşletmelerinin Yönetiminde Kritik Başarı Faktörlerinin Belirlenmesi Muğla Yöresinde Bir Alan Araştırması, Yayınlanmamış Yüksek Lisans Tezi, Muğla Üniversitesi, Muğla.

DiPietro, R. B., Murphy, K. S., Rivera, M. and Muller, C. C. (2007). Multi-Unit Management Key Success Factors in The Casual Dining Restaurant İndustry, International Journal of Contemporary Hospitality Management, 19(7): 524-536.

DiPietro, R. B., Parsa, H.G., and Gregory, A. (2011). Restaurant QSC inspections and financial performance: An Empirical Investigation, International Journal of Contemporary Hospitality Management, 23(7): 982-999.

Filizözü, B. (2010). Stratejik Planlamada Kritik Başarı Faktörleri: THY Örneği, Yayınlanmamış Yüksek Lisans Tezi, Hacettepe Üniversitesi, Ankara

Güler, S. (2007). Yiyecek ve İçecek İşletmeleri İçin Rekabet Avantajı Yaratacak Stratejik Seçenekler, Anatolia: Turizm Araştırmaları Dergisi, 18(1): 101-104

Heung, V.C.S. and Chu, R. (2000). Important Factors Affecting Hong Kong Consumers' Choice of a Travel Agency for All-Inclusive Package Tours, Journal of Travel Research, 39(1): 52-59.

http://www.turob.com/Files/Dosyalar/excel/02062020.xls [Erişim Tarihi: 20.07.2020]

https://trabzon.ktb.gov.tr/TR-164500/bakanligimizdan-turizm-isletme-belgeli-konaklama-tesisl.html, [Erişim Tarihi: 21.07.2020]

Hughes, M. and Carlsen, J. (2010). The business of cultural heritage tourism: critical success factors, Journal of Heritage Tourism, 5(1): 17-32.

Hussey, D. (1998). Strategic Management, From theory to implementation- Fourth Edition, Oxford: Butterworth Heinemann.

McLaren, L. (2011). Critical Marketing Success Factors for Sustainable Rural Tourism Routes: A Kwazulu-Natal Stakeholder Perspective, Yayınlanmamış M Phil. Tezi, University of Pretora, Güney Afrika.

Rockart, F. J. (1979). Chef Executives Define Their Own Data Needs, Harward Business Review, 57(2): 81-93.

Türkay, O., Kaya, M. C. ve Birer, Ş. (2013). Yiyecek-İçecek Çalışanlarının Mesleki Beklentilerinin Analizi: İstanbul Örneği, 14. Ulusal Turizm Kongresi, Erciyes Üniversitesi, 05-08 Aralık 2013. Kayseri. ss: 998-1015.

Ülgen, H. ve Mirze, S. K. (2013), İ̧sletmelerde Stratejik Yönetim, İstanbul: Beta Yayınları.

Wohlfeil, F. and Terzidis, O. (2014). Critical Success Factors for the Strategic Management of Radical Technological Innovation, International Conference on Engineering, Technology and Innovation (ICE), 23-25 Haziran 2014. Bergamo. ss:1-9. DOI: 10.1109/ICE.2014.6871529 
Yüksel, İ. ve Dağdeviren, M. (2009). Kritik Başarı Faktörleri Temelinde Göreli Rekabet Üstünlüğünün Belirlenmesi, 6.KOBI'ler ve Verimlilik Kongresi, İstanbul Kültür Üniversitesi, 17-18 Kasım 2009. İstanbul. s.s: 575-582. 